\title{
OSTEOPENIA OF PREMATURITY, CAN WE PREDICT IT? CAN WE STOP IT?
}

P O'Reilly, A Tou, M Saviani, N McCallion

Neonatology Department, Rotunda Hospital, Dublin, Ireland

\section{Introduction}

Very low birth weight (VLBW) infants are at risk of osteopenia of prematurity (OOP) and related skeletal fractures. ${ }^{1,2}$ Improved nutritional management in recent years should reduce the incidence of OOP. However, increased use of medications such as postnatal steroids, may have had a negative effect on bone health. ${ }^{3}$

It can be difficult to detect early signs of OOP and often the process is quite advanced by the time X-ray changes become evident.

Our aim was to examine which biochemical markers best predicted

radiologically significant OOP and thus better target our treatment and follow up in this vulnerable population.

\section{Results}

Of the 609 VLBW infants included in the study, $5.9 \%$ of these babies showed radiological evidence of OOP.

The average gestation of babies born with OOP was $26+3$ weeks and it took on average, 6.5 weeks for radiological evidence of OOP to be seen.

Table 2 compares the various biochemical markers associated with metabolic bone disease in the two groups. The highest alkaline phosphatase measurement recorded, duration of raised alkaline phosphatase and duration of low phosphate all were statistically significant predictors of OOP in our study.

\begin{tabular}{|c|c|c|c|}
\hline \multicolumn{4}{|c|}{ Results } \\
\hline & $\begin{array}{l}\text { Radiological evidence of OOP } \\
\mathrm{n}=36\end{array}$ & $\begin{array}{l}\begin{array}{l}\text { No evidence of OOP } \\
\mathrm{n}=573\end{array}\end{array}$ & p-value \\
\hline $\begin{array}{l}\text { Highest Alkaline Phosphatase } \\
\text { (IU/I) }\end{array}$ & $634(468,741)$ & $452(348,588)$ & $<0.001$ \\
\hline $\begin{array}{l}\text { Number of Recordings with } \\
\text { Alk Phos }>500 \mathrm{IU} / \mathrm{L} \text {. }\end{array}$ & $3(0,6)$ & $0(0,2)$ & $<0.001$ \\
\hline $\begin{array}{l}\text { Time with Alk Phos }>500 \mathrm{IU} / \mathrm{L} \\
\text { (days) }\end{array}$ & $8.5(0,29)$ & $0(0,2)$ & $<0.001$ \\
\hline $\begin{array}{l}\text { Number of Recordings of Alk } \\
\text { Phos }>900 \mathrm{IU} / \mathrm{L}\end{array}$ & $0(0,0)$ & $0(0,0)$ & 0.916 \\
\hline $\begin{array}{l}\text { Time with Alk Phos }>900 \mathrm{IU} / \mathrm{L} \\
\text { (days) }\end{array}$ & $0(0,0)$ & $0(0,0)$ & 0.918 \\
\hline $\begin{array}{l}\text { Lowest Phosphate } \\
(\mathrm{mmol} / \mathrm{l})\end{array}$ & $1.42(1.05,1.58)$ & $1.39(1.15,1.65)$ & 0.48 \\
\hline $\begin{array}{l}\text { Number of Recordings with } \\
\text { Phosphate }<1.8 \mathrm{mmol} / 1\end{array}$ & $6(3.25,8)$ & $4(1,7)$ & 0.011 \\
\hline $\begin{array}{l}\text { Time with phosphate } \\
<1.8 \mathrm{mmol} / / \text { (days) }\end{array}$ & $16(3,30.75)$ & $5(1,16)$ & 0.001 \\
\hline $\begin{array}{l}\text { Lowest Corrected Serum } \\
\text { Calcium (mmol/l) }\end{array}$ & $2.21(2.05,2.32)$ & $2.24(2.16,2.36)$ & 0.56 \\
\hline Lowest Vitamin D (nmol/1) & $44(30.25,57.75)$ & $54.5(28.75,91.5)$ & 0.0635 \\
\hline $\begin{array}{l}\text { Highest Parathyroid Hormone } \\
(\mathrm{pg} / \mathrm{ml})\end{array}$ & 12.5 & $23.5(10.9,52.9)$ & 0.800 \\
\hline Lowest Magnesium (mmol/]) & $0.81(.74,89)$ & $0.86(80,97)$ & 0.007 \\
\hline
\end{tabular}

\section{Methods}

We performed a retrospective review of all X-rays carried out on VLBW infants over a 5-year period in a tertiary neonatal centre. We also reviewed laboratory results in these babies. We compared the biochemical markers of OOP in those with and without radiological signs of OOP. We defined OOP radiologically as infants with Stage 1 and above X-ray changes as per Koo et. al. ${ }^{4}$
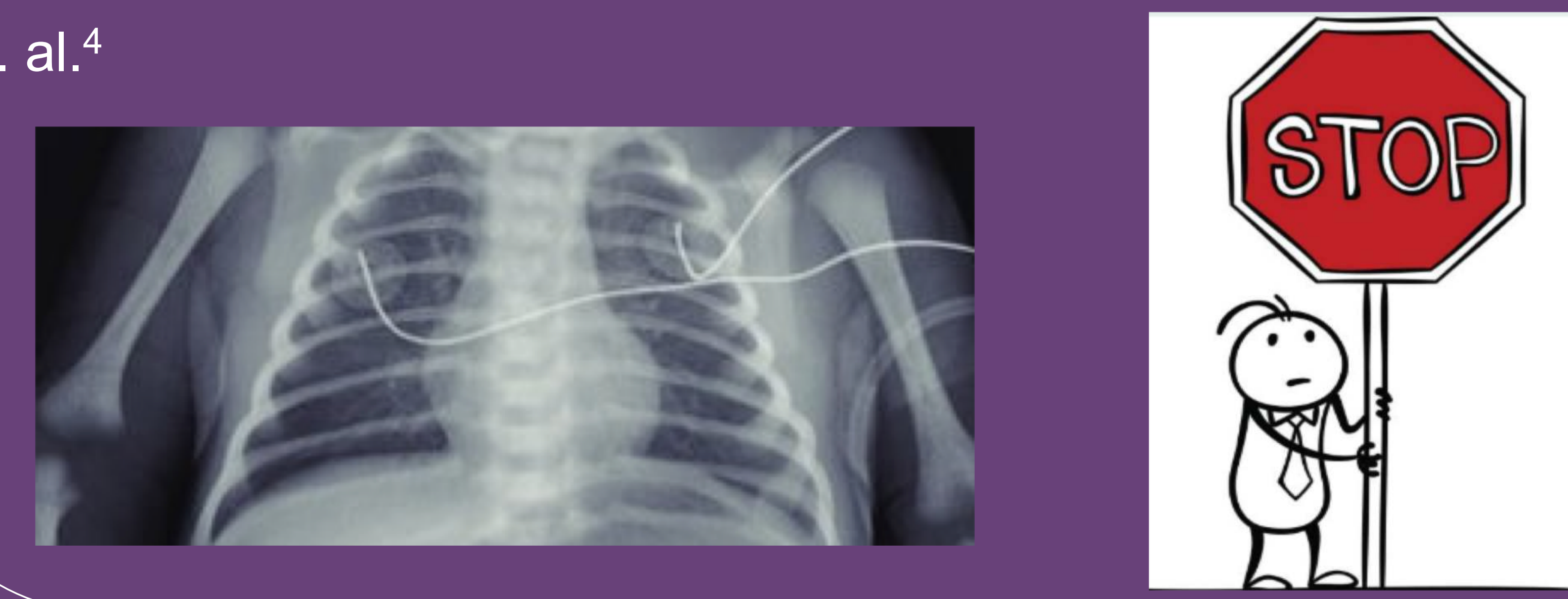

Results

\begin{tabular}{|c|c|c|c|c|}
\hline & $\begin{array}{l}\text { Radiological evidence } \\
\text { of } 00 \mathrm{P} \\
\mathrm{n}=36\end{array}$ & $\begin{array}{l}\text { No radiological evidence } \\
\text { of } 00 \mathrm{P} \\
\mathrm{n}=573\end{array}$ & $\begin{array}{l}\text { Total population } \\
\mathrm{n}=609\end{array}$ & p-value \\
\hline Birth Weight (grams) & $720(630,950)$ & $1117(860,1315)$ & $1100(840,1300)$ & $<0.001$ \\
\hline Length of Stay (days) & $78.5(55,97)$ & $38(23,56)$ & $40(34,58)$ & $<0.001$ \\
\hline Number of X-Rays & $22(13,35)$ & $5(2,11)$ & $5(2,12.5)$ & $<0.001$ \\
\hline Number of Chest X-Rays & $15.5(9,26)$ & $4(2,9)$ & $4(2,9)$ & $<0.001$ \\
\hline
\end{tabular}

Table 1 illustrates that the babies who showed evidence of OOP were, as expected, smaller and had longer hospital stays.

\section{Discussion}

We looked at several different markers of metabolic bone disease to see which best predicted radiological evidence of OOP. Of these, the time duration with elevated alkaline phosphatase and the time duration with low phosphate were strong predictors of OOP. Using this information it can be concluded that promptly correcting high alkaline phosphatase and low phosphate should have an impact on reducing OOP in these babies.

This emphasises the need to regularly monitor the markers of bone health in this population and to treat abnormal results swiftly. There is an opportunity to improve the bone health of the smallest babies with careful monitoring and management. 